\title{
Exchange Rate Dynamics and Monetary Policy in a Small Open Economy: A DSGE Model
}

\author{
Mariam OUCHEN ${ }^{1}$ Mustapha ZIKY ${ }^{2}$ Edward TOWER ${ }^{3}$ \\ 1. PhD Candidate University of Cadi Ayyad \\ 2. Professor of Economics University of Cadi Ayyad \\ 3. Professor of Economics Duke University
}

\begin{abstract}
This paper compares alternative monetary policy rules in a small open economy that experiences internal shocks (productivity shocks) and external shocks to terms of trade and the foreign demand. A comparison of the volatility of the macroeconomic variables such as inflation, output, terms of trade, trade balance, investment and exchange rates under the different monetary rules is set to lead to the choice of the optimal exchange rate regime. I will show that these regimes can be ranked in terms of their implied volatility for the considered macroeconomic variables. A two-country version of the Calvo sticky price model is used to analyze the macroeconomic implications of four alternative monetary policy regimes for a small open economy: domestic inflation targeting, managed float, CPI targeting and an exchange rate peg. The degree of exchange rate passthrough is very important for the assessment of monetary rules. I find that the CPI targeting rule is the best policy (from a macroeconomic stability viewpoint) in an economy that exhibits lagged exchange rate passthrough. With low pass-through, both the domestic and the overall prices respond sluggishly to shocks, and it is more efficient for the monetary authority to target the overall CPI rather than just domestic prices. In a low passthrough environment, the policy maker can simultaneously strictly target (CPI) inflation, but still allow high volatility in the nominal exchange rate to stabilize the real economy in face of shocks. The low rate of passthrough ensures that exchange rate shocks do not destabilize the price level. An important feature of low passthrough is that it eliminates the trade-off between output volatility and inflation volatility in the comparison of fixed relative to floating exchange rates.
\end{abstract}

Keywords: Exchange rate dynamics, the law of one price deviations, DSGE Models, Impulse Responses

\section{1-Introduction}

The objective of a realistic representation of how in practice monetary policy is conducted in open economies has motivated the work of Gali and Monacelli(2002),Benigno and Benigno (2002), Clarida, Gali and Gertler (2001).Yet a limitation shared by all these models is the assumption that the pass-through of exchange rates to (import) prices is complete. This lies in stark contrast to the well-established empirical evidence that deviations from the law of one price for traded goods are large and pervasive. This paper argues that allowing for incomplete pass-through bears important implications for the design of problems in optimal monetary policy.

To study the effects on the design of the optimal monetary policy of allowing for deviations from the law of one price in import goods, this paper develops a dynamic stochastic general-equilibrium (DSGE) model of a small open economy. This framework allows me to model alternative monetary rules, differing primarily in the degree to which they allow for exchange rate flexibility. 
Furthermore, I believe that this approach accords much better with the practice of modern central banks, and provides a more suitable framework for policy analysis than the traditional one. My assumptions on preferences and technology, combined with the Calvo price-setting structure and the assumption of complete financial markets, give rise to a highly tractable framework and to simple and intuitive log-linearized equilibrium conditions for the small open economy. Of course, the coefficients in the open economy's equilibrium also depend on parameters that are ascribed to the open economy (in this case, the degree of openness, the substitutability between domestic and foreign goods, and the pass-through), while the driving forces also include productivity shock, a foreign demand shock, and terms-of-trade shock.

The framework must be augmented with a system of equations describing how monetary policy is conducted. As hinted above, I employ this framework to analyze the macroeconomic implications of alternative monetary policy arrangements for the small open economy: (a) domestic inflation targeting, (b) managed float, (c) CPI targeting and (d) an exchange rate peg.

The analysis applies to the case of the Moroccan economy as a small open economy and its main trading partner: France as "the rest of the world" (Euro zone).

I show that these regimes can be ranked in terms of the implied volatility of macroeconomic variables. As established in the literature, policies that stabilize output require high exchange rate volatility, which implies high inflation volatility. However, with limited or delayed pass-through, the trade-off between output (or consumption) volatility and the volatility of inflation is much less pronounced. A flexible exchange rate policy that stabilizes output can do so without high inflation volatility. Finally, I show that a policy of CPI inflation targeting is much more desirable in an economy with limited pass-through.

\section{2-1.A Small Open Economy Model}

\subsection{1-Households}

Our small open economy is inhabited by a representative household who seeks to maximize

$E_{0} \sum_{t=0}^{\infty} \beta^{t}\left[U\left(C_{t}, N_{t}\right)\right]$, (1) where $N_{t}$ denotes hours of labor, and $C_{t}$ is a composite consumption index defined

by: $C_{t}=\left[(1-\alpha)^{\frac{1}{\eta}} C_{H, t}^{\frac{\eta-1}{\eta}}+\alpha^{\frac{1}{\eta}} C_{F, t}^{\frac{\eta-1}{\eta}}\right]^{\frac{\eta}{\eta-1}}$

$C_{H, t}$ is an index of consumption of domestic goods given by the CES function

$C_{H, t}=\left(\int_{0}^{1} C_{H, t}(j)^{\frac{\varepsilon-1}{\varepsilon}} d i\right)^{\frac{\varepsilon}{\varepsilon-1}}$

where $j \in[0,1]$ denotes the good variety. $C_{F, t}$ is an index of imported goods given $C_{F, t}=\left(\int_{0}^{1} C_{F, t}(j)^{\frac{\varepsilon-1}{\varepsilon}} d i\right)^{\frac{\varepsilon}{\varepsilon-1}}$

Notice that parameter $\mathcal{E}>1$ denotes the elasticity of substitution between varieties (produced within any given country). Parameter $\eta>0$ measures the substitutability between domestic and foreign goods, from the viewpoint of the domestic consumer.

The maximization of (1) is subject to a sequence of budget constraints of the form

$\int_{0}^{1}\left[P_{H, t}(i) C_{H, t}(i)+P_{F, t}(i) C_{F, t}(i)\right] d i+E_{t}\left\{Q_{t, t+1} D_{t+1}\right\} \leq D_{t}+W_{t} N_{t}+R_{t}^{k} K_{t}+T_{t}$

for $\mathrm{t}=0,1,2, \ldots$, where $P_{H, t}(i)$ and $P_{F, t}(i)$ denote the prices of domestic and foreign goods $i$ respectively.

$D_{t+1}$ is the nominal pay-off in period $t+1$ of the portfolio held at the end of period $t$ (and which includes shares in firms), $W_{t}$ is the nominal wage, $K_{t}$ is units of capital, $R_{t}^{k}$ is the return on capital, and $T_{t}$ denotes lump- 
sum transfers/taxes. All the previous variables are expressed in units of domestic currency. $Q_{t, t+1}$ is the stochastic discount factor for one-period ahead nominal pay-offs relevant to the domestic household. I assume that households have access to a complete set of contingent claims, traded internationally.

The optimal allocation of any given expenditure within each category of goods yields the demand functions:

$C_{H, t}(j)=\left(\frac{P_{H, t}(j)}{P_{H, t}}\right)^{-\varepsilon} C_{H, t} ; C_{F, t}(j)=\left(\frac{P_{F, t}(j)}{P_{i, t}}\right)^{-\varepsilon} C_{F, t}(4)$

For all $i, j \in[0,1]$, where $P_{H, t}=\left(\int_{0}^{1} P_{H, t}(j)^{1-\varepsilon} d i\right)^{\frac{1}{1-\varepsilon}}$ is the domestic price index (i.e. an index of prices of domestically produced goods) and $P_{F, t}=\left(\int_{0}^{1} P_{F, t}(j)^{1-\varepsilon} d i\right)^{\frac{1}{1-\varepsilon}}$ is a price index for goods imported from country $i$ (expressed in domestic currency), for all $i \in[0,1]$. Furthermore, the optimal allocation of expenditures between domestic and imported goods is given by:

$$
\begin{aligned}
C_{H, t} & =(1-\alpha)\left(\frac{P_{H, t}}{P_{t}}\right)^{-\eta} C_{t}(5) \\
C_{F, t} & =\alpha\left(\frac{P_{F, t}}{P_{t}}\right)^{-\eta} C_{t}(6)
\end{aligned}
$$

Where $P_{t}=\left[(1-\alpha) P_{H, t}{ }^{1-\eta}+\alpha P_{F, t}{ }^{1-\eta}\right]^{\frac{1}{1-\eta}}$ is the consumer price index (CPI). Accordingly, total consumption expenditures by domestic households are given by: $P_{H, t} C_{H, t}+P_{F, t} C_{F, t}=P_{t} C_{t}$. Thus, the period budget constraint can be rewritten as: $P_{t} C_{t}+E_{t}\left\{Q_{t, t+1} D_{t+1}\right\} \leq D_{t}+W_{t} N_{t}+R_{t}^{k} K_{t}+T_{t} \quad$ (7)

In what follows I specialize the period utility function to take the form

$U(C, N)=\frac{C_{t}{ }^{1-\sigma}}{1-\sigma}-\frac{N_{t}{ }^{1+\varphi}}{1+\varphi}$.

Then I can rewrite the remaining optimality conditions for the household's problem as follows:

$C^{\sigma} N^{\varphi}=\frac{W_{t}}{P_{t}}$

which is a standard intratemporal optimality condition, and $\beta\left(\frac{C_{t+1}}{C_{t}}\right)^{-\sigma}\left(\frac{P_{t}}{P_{t+1}}\right)=Q_{t, t+1}$

Taking conditional expectations on both sides of (8) and rearranging terms, I obtain a conventional stochastic Euler equation:

$\beta R_{t} E_{t}\left\{\left(\frac{C_{t+1}}{C_{t}}\right)^{-\sigma}\left(\frac{P_{t}}{P_{t+1}}\right)\right\}=1$

where $R_{t}^{-1}=E_{t}\left\{Q_{t, t+1}\right\}$ is the gross return on a riskless one-period discount bond paying off one unit of domestic currency in $\mathrm{t}+1$ (with its price denominated in domestic currency) and, hence, $R_{t}$ is its gross return. For future reference it is useful to note that (8) and (9) can be written in log-linearized form as:

$w_{t}-p_{t}=\sigma c_{t}+\varphi n_{t}(11)$

$c_{t}=E_{t}\left\{c_{t+1}\right\}-\frac{1}{\sigma}\left(r_{t}-E_{t}\left\{\pi_{t+1}\right\}-\rho\right)$

where lower case letters denote the $\operatorname{logs}$ of the respective variables, $\rho=-\log \beta$ is the time discount rate, and $\pi_{t}=p_{t}-p_{t-1}$ is CPI inflation (with $p_{t}=\log P_{t}$ ).

In the rest of the world (which, for convenience, I refer to as the world economy), a representative household faces a problem identical to the one outlined above. A set of analogous optimality conditions characterize the 
solution to the consumer's problem in the world economy. I assume, however, that the size of the small open economy is negligible relative to the rest of the world, which allows us to treat the latter as if it were a closed economy.

\subsection{2-Domestic Inflation, CPI Inflation, the Real Exchange Rate, the Terms of Trade and the law of one} price deviation: Some Identities

Before proceeding with my analysis of the economy's equilibrium, I introduce several assumptions and definitions, and derive a number of identities that are extensively used below.

The terms of trade can be written in log-linear form: $s_{t}=p_{F, t}-p_{H, t}(13)$. The terms of trade are thus the price of foreign goods in terms of home goods.

Thus, log-linearization of the CPI formula around the steady state yields the following relationship between aggregate prices and terms of trade:

$$
\begin{aligned}
& p_{t}=(1-\alpha) p_{H, t}+\alpha \\
= & p_{H, t}+\alpha s_{t}
\end{aligned}
$$

It follows that domestic inflation (defined as the rate of change in the index of domestic goods prices, $\pi_{H, t}=$ $\left.p_{H, t}-p_{H, t-1}\right)$ and CPI inflation are linked according to $\pi_{t}=\pi_{H, t}+\alpha \Delta s_{t}$ (15)

Unlike Gali and Monacelli(2002) and Gali(2008), I assume throughout that the law of one price does not hold and I define $\varepsilon_{t}$ as the nominal exchange rate(the price of the foreign currency in terms of the domestic currency). An increase in $\varepsilon_{t}$ coincides with a depreciation of the domestic currency. The real exchange rate and the law of one price (LOP) gap are respectively defined as follow:

$Q_{t}=\frac{\varepsilon_{t} P_{t}^{*}}{P_{t}}$ which can be written as a log-linear form : $q_{t}=e_{t}+p_{t}^{*}-p_{t}(16)$

and $\Psi_{t}=\frac{\varepsilon_{t, P_{t}^{*}}^{*}}{P_{F, t}}(17)$.

Substituting $\psi_{t}=\ln \Psi_{t}$ into (17) and log-linearizing I get: $\psi_{t}=e_{t}+p_{t}^{*}-p_{F, t}(18)$

Using (16): $q_{t}=e_{t}+p_{t}^{*}-p_{t}$, the definition of the terms of trade (13): $s_{t}=p_{F, t}-p_{H, t}$ and (14): $p_{t}=p_{H, t}+$ $\alpha s_{t}$, I get: $\psi_{t}=q_{t}-(1-\alpha) s_{t}(19)$

\subsection{3-International Risk Sharing}

Under the assumption of complete securities markets, a first order condition analogous to (9) must also hold for consumers in the foreign country: $\beta\left(\frac{C_{t+1}^{*}}{C_{t}^{*}}\right)^{-\sigma}\left(\frac{P_{t}^{*}}{P_{t+1}^{*}}\right) \frac{\varepsilon_{t}^{*}}{\varepsilon_{t+1}^{*}}=Q_{t, t+1}(20)$

Combining (9) and (20), together with the real exchange rate definition, it follows that: $C_{t}=C_{t}^{*} Q_{t}^{\frac{1}{\sigma}}(21)$

Taking logs on both sides of (21), I obtain: $c_{t}=c_{t}^{*}+\left(\frac{1}{\sigma}\right) q_{t}$

\subsection{4-Uncovered Interest Parity and the Terms of Trade}

Under the assumption of complete international financial markets, the equilibrium price (in terms of domestic currency) of a riskless bond denominated in foreign currency is given by $\varepsilon_{i, t}\left(R_{t}^{i}\right)^{-1}=E_{t}\left\{Q_{t, t+1} \varepsilon_{i, t+1}\right\}$. The 
previous pricing equation can be combined with the domestic bond pricing equation, $R_{t}^{-1}=E_{t}\left\{Q_{t, t+1}\right\}$ to obtain a version of the uncovered interest parity condition: $E_{t}\left\{Q_{t, t+1} R_{t-} R_{t}^{i}\left[\left(\varepsilon_{i, t+1} / \varepsilon_{i, t}\right)\right]\right\}=0$.

Linearization around a perfect-foresight steady state yields the familiar expression: $r_{t-} r_{t}^{*}=E_{t}\left\{\Delta e_{t+1}\right\}$

Combining the definition of the $(\log )$ real exchange rate with (23) yields the following stochastic difference equation: $\Delta E_{t} q_{t+1}=\left(r_{t}-\left\{\pi_{t+1}\right\}\right)-\left(r_{t}^{*}-\left\{\pi_{t+1}^{*}\right\}\right)$ (24).

\section{2-Firms}

\subsection{1-Technology}

Each firm produces a differentiated good with a linear technology represented by the production function: $Y_{t}(j)=A_{t} K_{t}^{\chi}(j) N_{t}(j)^{1-\chi}(25)$ where $a_{t}=\log A_{t}$ follows an $\mathrm{AR}(1)$ process: $a_{t}=\rho_{a} a_{t-1}+\varepsilon_{t}$, describing the firm specific productivity index, $j \in[0,1]$ is a firm-specific index and $N_{t}$ is the number of hours worked. Aggregate output can be written as: $Y_{t}=\left[\int_{0}^{1} Y_{t}(j)^{1-\frac{1}{\varepsilon}} d j\right]^{\frac{\varepsilon}{\varepsilon-1}}$

Assuming a symmetric equilibrium across all $j$ firms, the first order log-linear approximation of the aggregate production function can be written as: $y_{t}=\chi k_{t}+(1-\chi) n_{t}+a_{t}$ (27)

Each period the firm maximizes profits:

$\max P_{t} Y_{t}-W_{t} N_{t}-R_{t}^{k} K_{t}(28)$

\section{Subject to (25)}

where $W_{t}$ is wage $R_{t}^{k}$ is the return on capital and $P_{t}$ is the price.

Maximization of (28) subject to (25) yields the optimality condition

$$
M C_{t}=\frac{W_{t}}{(1-\alpha) A_{t} K^{\chi} N^{-\chi}}=\frac{W_{t}}{M P N_{t}}=\frac{W_{t} N_{t}}{(1-\alpha) Y_{t}} .
$$

Hence, the real marginal cost (expressed in terms of domestic prices) will be common across firms and given by:

$$
m c_{t}=w_{t}+n_{t}-\log (1-\chi)-y_{t} .
$$

Firms in the rest of the world are assumed to produce goods using a linear technology represented by the production function: $Y_{t}^{*}(i)=A^{*} N_{t}^{*}(i)$.

with (log) productivity following an exogenous process $a_{t}^{*}=\rho_{a}^{*} a_{t-1}^{*}+\varepsilon_{t}^{*}$ and where $\left\{\varepsilon_{t}^{*}\right\}$ is white noise, possibly correlated with $\left\{\varepsilon_{t}\right\}$. Finally, an approximate aggregate relationship between output and employment can be expressed as follows $y_{t}^{*}=n_{t}^{*}+a_{t}^{*}$

\subsection{2-Domestic Producers}

I assume that firms set prices in a staggered fashion, as in Calvo (1983). Hence, a measure $1-\theta_{H}$ of (randomly selected) firms sets new prices each period, with an individual firm's probability of reoptimizing in any given period being independent of the time elapsed since it last reset its price.

A firm re-optimizing in period $\mathrm{t}$ will choose the price $P_{H, t}^{*}$ that maximizes the current market value of the profits generated.

The problem of the firm is to select $P_{t}^{*}$ so as to maximize: 
$\max _{\mathrm{p}_{\mathrm{Hit}}^{*}} \sum_{\mathrm{k}=0}^{\infty} \theta^{\mathrm{k}} \mathrm{E}_{\mathrm{t}}\left\{\mathrm{Q}_{\mathrm{t}+\mathrm{k}}\left(\mathrm{P}_{\mathrm{H}, \mathrm{it}}^{*} \mathrm{Y}_{\mathrm{it}+\mathrm{k}}-\mathrm{P}_{\mathrm{H}, \mathrm{t}+\mathrm{k}} \mathrm{mc}_{\mathrm{it}+\mathrm{k}} \mathrm{Y}_{\mathrm{it}+\mathrm{k}}\right)\right\}$.

where $m c_{t+k}$ is the real marginal cost.

Subject to the demand constraints: $Y_{i t+k}=\left(\frac{P_{i t}^{*}}{P_{t+k}}\right)^{-\mathcal{E}} Y_{t+k}$.

For $k=0,1,2 \ldots$ where $Q_{t+k}$ is the discount factor of households, and $Y_{t+k}$ denotes output in period $t+k$ for a firm that last reset its price in period t.

The price-setting behavior for the domestic producers could be summarized as:

$$
P_{H, t}^{*}-P_{H, t-1}=(1-\beta \theta) \sum_{k=0}^{\infty}(\beta \theta)^{k} E_{t}\left\{\widehat{m c}_{t+k}\right\}+\sum_{k=0}^{\infty}(\beta \theta)^{k} E_{t}\left\{\pi_{H, t+k}\right\}
$$

where $\widehat{m c}_{t+k}=m c_{t+k}-m c$ denotes the log deviation of marginal cost from its steady state value $m c=-\mu$, and where $\mu=\log \frac{\varepsilon}{\mathcal{E}-1}$ is the $\log$ of the desired gross markup.

Rearranging terms and combining the price setting behavior and the aggregate price level I get:

$\pi_{H, t}=\beta E_{t} \pi_{H, t+1}+\lambda_{H} \widehat{m c}_{t}(32)$, which is the new Keynesian Philips curve

where $\lambda_{H}=\frac{\left(1-\theta_{H}\right)\left(1-\beta \theta_{H}\right)}{\theta_{H}}$.

\subsection{3- Price-setting behavior and incomplete pass-through}

I now turn to discuss the dynamic of import pricing. Here I assume the law of one price (LOP) holds at the wholesale level for imports. However, inefficiency in distribution channels together with monopolistic retailers keep domestic import prices over and above the marginal cost. As a result, the LOP fails to hold at the retail level for domestic imports.

Following a similar Calvo-pricing argument as in the domestic producers' price, the price-setting behavior for the domestic importer retailers could be summarized as:

$P_{F, t}^{*}-P_{F, t-1}=\left(1-\beta \theta_{F}\right) \sum_{k=0}^{\infty}\left(\beta \theta_{F}\right)^{k} E_{t}\left\{\widehat{\psi}_{t+k}\right\}+\sum_{k=0}^{\infty}\left(\beta \theta_{F}\right)^{k} E_{t}\left\{\pi_{F, t+k}\right\}$ (33).

where $\theta_{F} \in[0,1]$ is the fraction of import retailers that cannot re-optimize their prices every period. Substituting equation (33) into the determination of $\pi_{F, t}$ arising from the Calvo-pricing structure yields:

$$
\pi_{\mathrm{F}, \mathrm{t}}=\beta \mathrm{E}_{\mathrm{t}} \pi_{\mathrm{F}, \mathrm{t}+1}+\lambda_{\mathrm{F}} \psi_{\mathrm{t}}(34) \text {, where } \lambda_{\mathrm{F}, \mathrm{t}}=\frac{\left(1-\theta_{\mathrm{F}, \mathrm{t}}\left(1-\beta \theta_{\mathrm{F}, \mathrm{t}}\right)\right.}{\theta_{\mathrm{F}, \mathrm{t}}}
$$

Log-linearizing the definition of CPI and taking the first difference yields the following relationship for overall inflation: $\pi_{t}=(1-\alpha) \pi_{H, t}+\alpha \pi_{F, t}(35)$

\subsection{4-Capital Producers}

Entrepreneurs purchase capital in each period for use in the subsequent period. Capital is used in combination with hired labor to produce (wholesale) output. I assume that production is constant returns to scale, which allows me to write the production function as an aggregate relationship. I specify the aggregate production function relevant to any given period $t$ as $Y_{t}=A_{t} K_{t}^{\chi} N_{t}{ }^{1-\chi}$

where $Y_{t}$ is aggregate output of wholesale goods, $K_{t}$ is the aggregate amount of capital purchased by entrepreneurs in period $t-1, N_{t}$ is labor input, and $A_{t}$ is an exogenous technology parameter. Let $I_{t}$ denote 
aggregate investment expenditures. The aggregate capital stock evolves according to the following law of motion: $k_{t}=(1-\delta) K_{t-1}+i_{t}$, where $\delta$ is the depreciation rate.

\section{Equilibrium}

\section{1- Consumption and output in the small open economy.}

Goods market clearing in the representative small open economy ("home") requires:

$$
y_{t}=(1-\alpha)\left(C_{H, t}+i_{H, t}\right)+\alpha C_{H, t}^{*}
$$

where $C_{H, t}^{*}$ denotes the foreign country's demand for goods produced in the home economy and $I_{H, t}$ is the domestic investment.

Acknowledging that $C_{H, t}=(1-\alpha)\left(\frac{P_{H, t}}{P_{t}}\right)^{-\eta} C_{t}, C_{H, t}^{*}=\alpha\left(\frac{P_{H, t}}{P_{t}}\right)^{-\eta} C_{t}^{*}=\alpha\left(\frac{P_{H, t}}{\varepsilon_{t} P_{t}^{*}}\right)^{-\eta} C_{t}^{*}$

and $I_{H, t}=(1-\alpha)\left(\frac{P_{H, t}}{P_{t}}\right)^{-\eta} I_{t}$

Log-linearizing the above three functions gives:

$$
\begin{aligned}
& c_{H, t}=\alpha \eta s_{t}+c_{t}(37) \\
& C_{H, t}^{*}=\eta\left(s_{t}+\psi_{t}\right)+c_{t}^{*} \\
& i_{H, t}=\alpha \eta s_{t}+i_{t}(39)
\end{aligned}
$$

Substituting equations (37), (38), and (39) into (40) yields the goods market clearing condition for the small open economy: $y_{t}=(1-\alpha)\left(\alpha \eta s_{t}+c_{t}\right)+\alpha\left(\left(\eta+s_{t}\right)+\psi_{t}+y_{t}^{*}\right)+(1-\alpha)\left(\alpha \eta s_{t}+i_{t}\right)(40)$

\section{2-The trade Balance}

Let $N X_{t}=\frac{P_{H t} Y_{t}-P_{t} C_{t}-P_{t} I_{t}}{P_{t}}(41)$

where $N X_{t}$ are the net exports

A first-order approximation yields:

$\eta x_{t} \approx y_{t}-c_{t}-2 \alpha s_{t}-i_{t}(42)$.

4-The supply side: marginal cost and inflation dynamics in the small open economy.

In the small open economy, the dynamics of domestic inflation in terms of real marginal cost are described by:

$$
\pi_{H, t}=\beta E_{t}\left\{\pi_{H, t+1}\right\}+\lambda \widehat{m c}_{t}
$$

The determination of the real marginal cost as a function of domestic output in the small open economy differs somewhat from that in the closed economy, due to the existence of a wedge between output and consumption, and between domestic and consumer prices. Thus, in this model I have:

$$
\mathrm{mc}_{\mathrm{t}}=\sigma \mathrm{y}_{\mathrm{t}}^{*}+\psi_{\mathrm{t}}+\mathrm{s}_{\mathrm{t}}+\mathrm{y}_{\mathrm{t}}\left(\frac{1+\varphi}{1-\chi}-1\right)-\left(\frac{\varphi+1}{1-\chi}\right)\left(\mathrm{a}_{\mathrm{t}}+\chi \mathrm{k}_{\mathrm{t}}\right)(44)
$$

\section{5-Monetary Policy Rules in the Small Open Economy}

In the present section, I analyze the macroeconomic implications of four alternative monetary policy regimes for the small open economy: a policy that aims at fully stabilizing domestic inflation (domestic inflation targeting, or DIT, for short), a policy that stabilizes both CPI inflation and exchange rate (managed float or MF for short), a policy that stabilizes CPI inflation (CPI targeting or CIT for short) and a policy that pegs the exchange rate to the world currency (a PEG, for short). In all cases I assume that the world monetary authority succeeds in fully stabilizing world prices and the output. 


\section{1-Domestic Inflation Targeting}

The domestic inflation targeting rule implies:

$r_{t}=\beta_{0} r_{t-1}+\left(1-\beta_{0}\right)\left(\beta_{1} \pi_{H, t}+\beta_{2} y_{t}\right)+\varepsilon_{r, t}, \quad \varepsilon_{r, t} \sim$ i. i. $d\left(0, \sigma_{e, r}^{2}\right)$

$r_{t}, \pi_{H, t}$ and $y_{t}$ are $(\log )$ deviation of the interest rate, domestic inflation and output respectively, from their steady-state values. $\beta_{1}$ and $\beta_{2}$ are the coefficients that measure central bank responses to deviations of inflation, and the output from their target.

$0<\beta_{0}<1$ is the interest rate smoothing parameter.

\section{2-Managed float policies}

I follow Monacelli (2004), who shows that a positive coefficient on exchange rate variation in a monetary policy rule can be used to model a managed float exchange rate. The monetary authority practices the managed exchange rate regime according to the following Taylor-type rule:

$r_{t}=\beta_{0} r_{t-1}+\left(1-\beta_{0}\right)\left(\beta_{1} \pi_{t}+\beta_{2} y_{t}+\beta_{3} e_{t}\right)+\varepsilon_{r, t}, \quad \varepsilon_{r, t} \sim$ i.i.d $\left(0, \sigma_{e, r}^{2}\right)$

where $r_{t}, \pi_{t}, y_{t}$ and $e_{t}$ are (log) deviation of the interest rate, inflation, output, and the exchange rate, respectively, from their steady-state values. $\beta_{1}, \beta_{2}$ and $\beta_{3}$ are the coefficients that measure central bank responses to deviations of inflation, output, and exchange rate from their target.

$0<\beta_{0}<1$ is the interest rate smoothing parameter.

\section{3- CPI Inflation Targeting}

Under the regime analyzed here the monetary authority of the small economy seeks to stabilize CPI inflation (as opposed to domestic inflation). Formally, such a policy requires:

$$
r_{t}=\beta_{0} r_{t-1}+\left(1-\beta_{0}\right)\left(\beta_{1} \pi_{t}+\beta_{2} y_{t}\right)+\varepsilon_{r, t}
$$

\section{4- An Exchange Rate Peg}

The fourth monetary arrangement for the small open economy consists of a permanent (and credible) exchange rate peg vis a vis the rest of the world. In the context of this model, this is equivalent to the adoption of the world currency by the small economy, with the corresponding relinquishment of an autonomous monetary policy. For simplicity, I maintain the assumption of an optimal monetary policy for the world economy. Following Gali and Monacelli (2002) and Gali (2008) and according to the uncovered interest parity (23), the exchange rate peg requires: $e_{t}=e_{t-1}$.

where $e_{t}$ is the nominal exchange rate.

\section{Calibration of the model and simulation results}

In this section I present some quantitative results based on a calibrated version of the model using data of Morocco and France. 
Table 1: Calibration of the model

\begin{tabular}{|c|c|c|c|}
\hline Description & arameter & Value & Reference \\
\hline \multicolumn{4}{|l|}{ Preferences } \\
\hline Subjective discount factor & $\beta$ & 0.94 & $\begin{array}{l}\text { Bank Al Maghrib } \\
(2005-2012)\end{array}$ \\
\hline $\begin{array}{l}\text { Inverse intertemporal elasticity of } \\
\text { substitution in consumption }\end{array}$ & $\sigma$ & 1 & King-Plosser-Rebello(1988) \\
\hline $\begin{array}{l}\text { Elasticity of substitution between domestic } \\
\text { and imported goods }\end{array}$ & $\eta$ & 0.37 & Abdelkhalek, T. (1996) \\
\hline $\begin{array}{l}\text { Elasticity of substitution between goods } \\
\text { within the same category }\end{array}$ & $\varepsilon$ & 6 & Gali and Monacelli(2002) \\
\hline \multicolumn{4}{|l|}{ Technology } \\
\hline The capital share in Morocco & $\chi$ & 0.37 & Abdelkhalek, T. (1996) \\
\hline The capital share in France & $\varpi$ & 0.75 & Rholand Dorhem(2012) \\
\hline Capital depreciation rate & $\delta$ & 0.05 & $\begin{array}{l}\mathrm{HCP} \\
(2005)\end{array}$ \\
\hline Probability of not adjusting prices & $\theta_{H}$ & 0.75 & Gertler et al(2007) \\
\hline \multicolumn{4}{|l|}{ Monetary Policy } \\
\hline Smoothing coefficient in the monetary rule & $\beta_{0}$ & 0.5 & Gertler et al(2007) \\
\hline Inflation stabilizing coefficient & $\beta_{1}$ & 2.5 & Monacelli(2002) \\
\hline Output Stabilizing coefficient & $\beta_{2}$ & 2.5 & Gertler et al(2007) \\
\hline NER targeting coefficient & $\beta_{3}$ & 0.5 & Monacelli(2004) \\
\hline Persistence parameter of terms of trade shock & $\rho_{s}$ & 0.8 & \\
\hline Persistence of technology shock & $\rho_{a}$ & 0.97 & \\
\hline Persistence of demand shock & $\rho_{y^{*}}$ & 0.95 & \\
\hline \multicolumn{4}{|l|}{ Other Parameters } \\
\hline The degree of Openness & $\alpha$ & 0.47 & \\
\hline The pass-through & $\theta_{F}$ & 0.75 & Goldfajn et Werlang (2000) \\
\hline
\end{tabular}

\section{Results}

\subsection{A positive productivity shock}

Figure 1 displays the dynamics of the main variables in response to a one-unit innovation in $\mathrm{a}_{\mathrm{t}}$ under the four monetary regimes (the domestic inflation targeting DIT, the managed float MF, the consumption price index targeting CIT, and the peg PEG, when the pass-through from exchange rates to imported goods prices is delayed). Notice that the inflation and nominal interest rates are reported as annualized quarterly rates, while the quantities are reported as log deviation from steady state (i.e., percentage deviations). There are many interesting features worth noting with the estimated, impulse response functions.

A persistent growth in factor productivity would lead to augmentation of equilibrium investment, consumption, and output. This shock induces a decrease in marginal cost and domestic inflation, an increase in import and imported inflation, and a decrease in the overall inflation. The overall inflation falls under the four regimes, but the magnitude of the response to the productivity disturbance is affected quite strongly by the monetary rule. The 
response of the overall inflation under the MF and the PEG is almost the same, while it is effectively stabilized under CIT. The lower response of inflation in CIT dramatically limits the magnitude of the rise in nominal interest rate, which generates a nominal appreciation. The increase in both import and investment leads to a trade balance deficit. Under DIT and MF, the central bank revises upwardly the nominal interest rate for stabilizing the expected inflation, while the former remains unchanged in the PEG, which is a direct implication of the corresponding relinquishment of an autonomous monetary policy under this regime. Given the constancy of the world nominal interest rate, the uncovered interest parity implies an initial nominal depreciation followed by expectations of a future appreciation, as reflected in the response of the nominal exchange rate.

The response of the LOP gap to a positive productivity shock is consistent with Monacelli (2003), who showed that for a sufficiently low degree of pass-through, the LOP gap must respond positively to a productivity shock. In particular, notice that PEG implies a complete stabilization of the LOP gap, but also generates a larger volatility in both domestic and CPI inflation relative to DIT and CIT, and a larger volatility in the output relative to CIT. Finally, the impulse responses of different variables show that shock effects are more cushioned under the CIT regime than under the three remaining regimes that face a productivity shock.

Figure 1: Impulse responses to a Productivity Shock: delayed pass-through
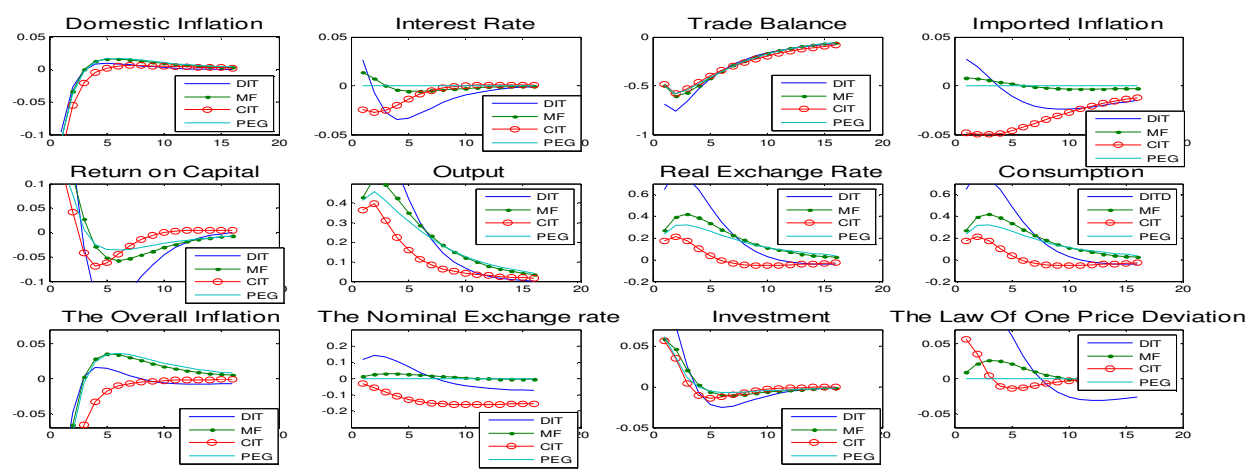

Figure 2 illustrates the case of full pass-through. With full pass-through, changes in exchange rates feed immediately into the CPI. For the four rules, the immediate pass-through raises the rate of inflation. Under the DIT rule with delayed pass-through, the movement in inflation is only $10 \%$ of the movement with immediate pass-through. This destabilizes the real economy (relative to the limited pass-through). The higher response of inflation now allows for a higher response in real interest rate to the productivity shock. The responses of output, consumption, trade balance, and real exchange rate under the productivity shock are quite similar. Under CIT, and to a lesser extent DIT, the inflation rate is effectively stabilized. A clear implication of figure 2, however, is that the monetary rules that provide inflation stability do so at the expense of exchange rate stability. The DIT rule stabilizes the domestic inflation rate, but does so at the expense of stability in the nominal exchange rate. 
Figure 2: Impulse responses to a Productivity Shock: full pass-through
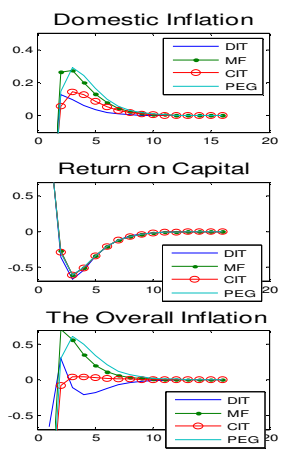

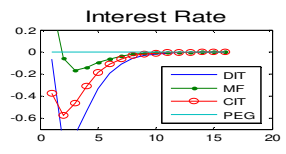

Output
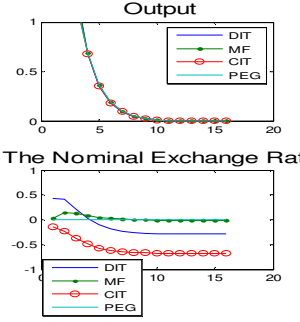
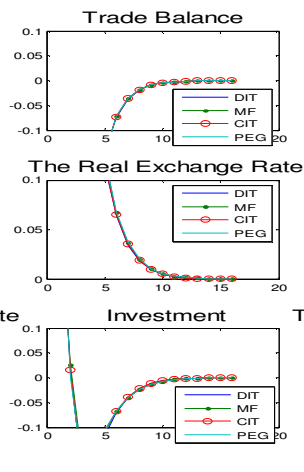
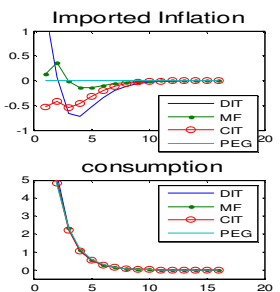

he Law of One Price Deviation

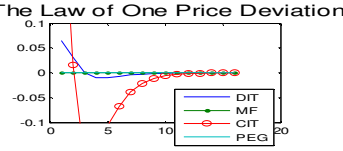

\section{2- A positive foreign demand shock}

Under the four monetary regimes, the dynamics of the variables in response to a one-standard deviation rise in current exports with delayed pass-through are depicted in figure 3 . The shock induces a positive effect on output and investment. The DIT, CIT, and MF rules allow for a nominal appreciation followed by expectations of a future depreciation. The anticipated depreciation allows for a proportional rise in the nominal interest rate, while the rate remains unchanged in the peg (an initial drop in interest rate is caused by the decrease in inflation). Given that the nominal depreciation under the MF is the lowest, this rule becomes much more expansionary than DIT and CIT as illustrated in the response of the interest rate.

This positive demand shock induces an increase in net exports and leads to a trade balance surplus, except for the PEG where the sharp increase in both consumption and investment leads to an initial trade deficit. As a result of the rise of the nominal interest rate, a decline in both the consumption and the overall inflation rate under CIT and DIT is observed. The fall in the world prices decreases the LOP gap in PEG and in MF. Consequently, the imported, the domestic, and the overall inflation in PEG and in MF decrease. The pegged exchange rate requires a greater response in output, inflation, consumption, trade balance and investment than the other rules. Notice that the responses of output and inflation in PEG are qualitatively similar to the CIT and DIT cases. However, the impossibility of raising the nominal rate and letting the currency appreciate, which would be needed to stabilize the expansion in consumption and output required to replicate the flexible price allocation, results in an amplification of the same responses and further volatility in inflation and output. Thus, the CIT regime achieved full stabilization of output and inflation, but at the cost of boosting the instability of the exchange rates. The converse was true for the exchange rate peg, where DIT emerged as a hybrid regime.

Finally, when comparing CIT, MF, PEG, and DIT, notice that the first regime provided more stability than the three others which showed that CIT was more desirable when facing a foreign demand shock. 
Figure 3: Impulse responses to a Foreign Demand Shock: delayed pass-through
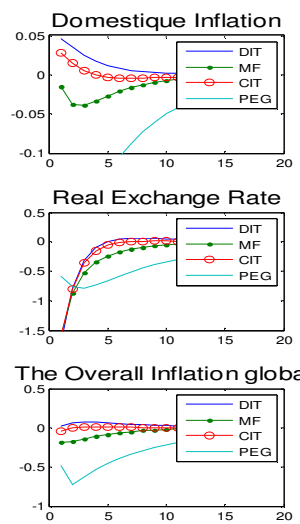
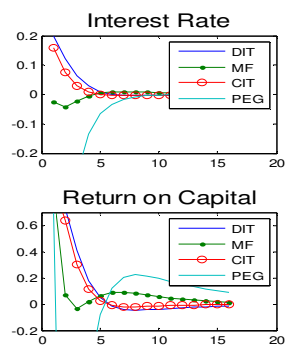

Nominal Exchange Rate

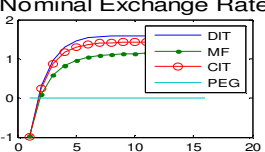

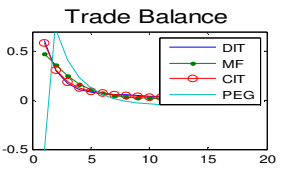

Output

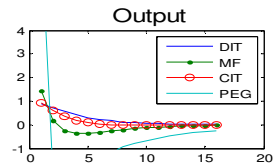

Investment

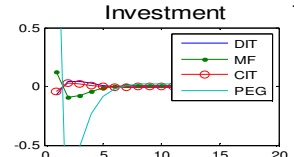

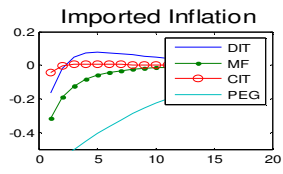
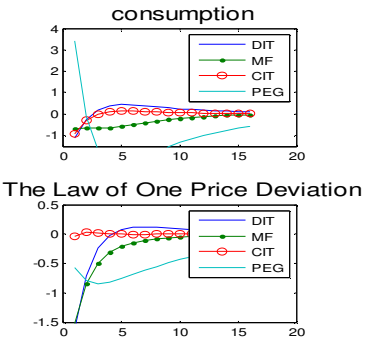

Figure 4 illustrates the impact of a foreign demand shock with full-pass-through. Again, as before, the effect of immediate pass-through is to reinforce the inflationary impact of shocks, while stabilizing the real economy, because the direct impact of the price shock is immediately felt in consumer prices. The absolute response of inflation and output is greatest under the pegged exchange rate as in the delayed pass-through .The nominal exchange rate response is more stable than in the case of limited pass-through .The DIT, CIT, and MF imply a persistent nominal appreciation and consequently a fall in the nominal interest rate except for DIT. In the DIT rule, monetary authorities increase the nominal interest rate to cope with expansionary effects of the shock(output and consumption in DIT are more persistent and require a higher interest rate to return back to the steady state position). In terms of stabilizing output, consumption, real exchange rate, investment and trade balance, CIT and MF are essentially equivalent when there is full pass-through.

Figure 4: Impulse responses to a Foreign Demand Shock: full pass-through
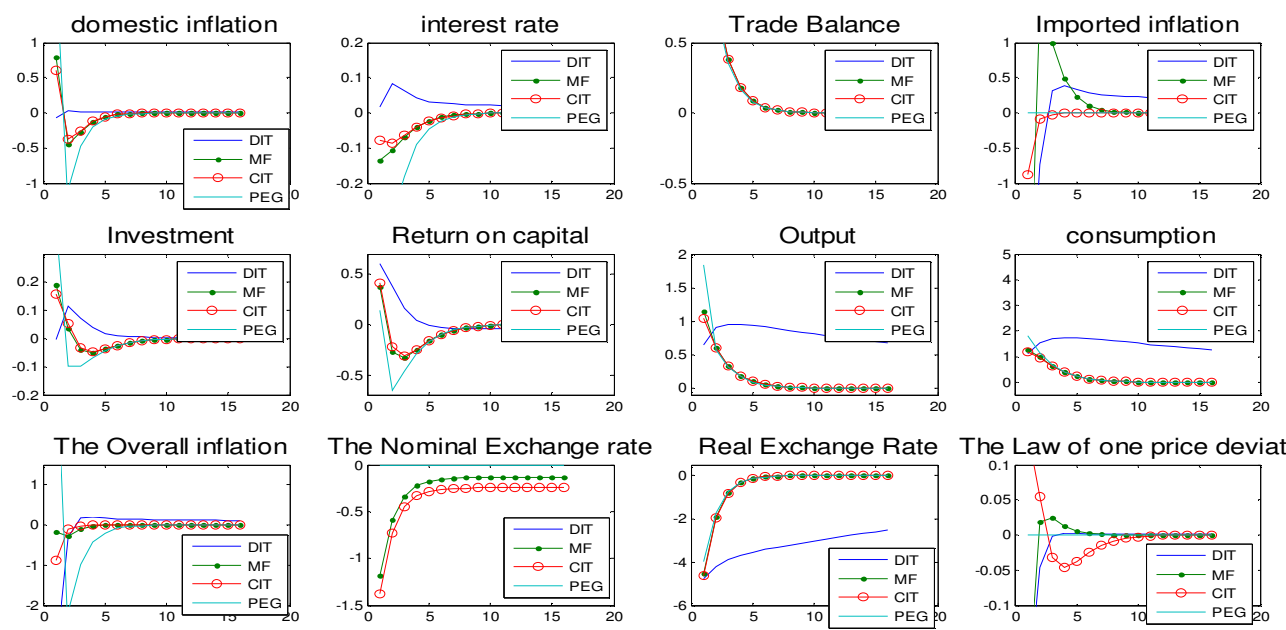

\section{3-Terms of trade Shock}

Figure 5 displays the impulse responses to a unit innovation in terms of trade under the four regimes considered with delayed-pass-through, while figure 6 illustrates the case of immediate pass-through.

The shock induces a negative effect on output. Notice also that the shock leads to an initial depreciation followed by a persistent appreciation. The initial and transitory nominal depreciation followed by expectations of a future appreciation of the exchange rate leads the central bank to decrease the nominal interest rate proportionally to the 
exchange rate responses. The more muted appreciation under the MF rule (relative to DIT and CIT) requires a less expansionary policy (a higher interest rate), while the interest rate remains unchanged in the peg (an initial rise in interest rates is caused by an increase in inflation). The decrease in interest rate in CIT and DIT leads to a greater increase in consumption and investment and, consequently, to an initial trade deficit, while under PEG, the rise in interest rate induces adverse effects on both consumption and investment and generates a transitory trade surplus.

Figure 5: Impulse responses to terms of trade Shock delayed pass-through
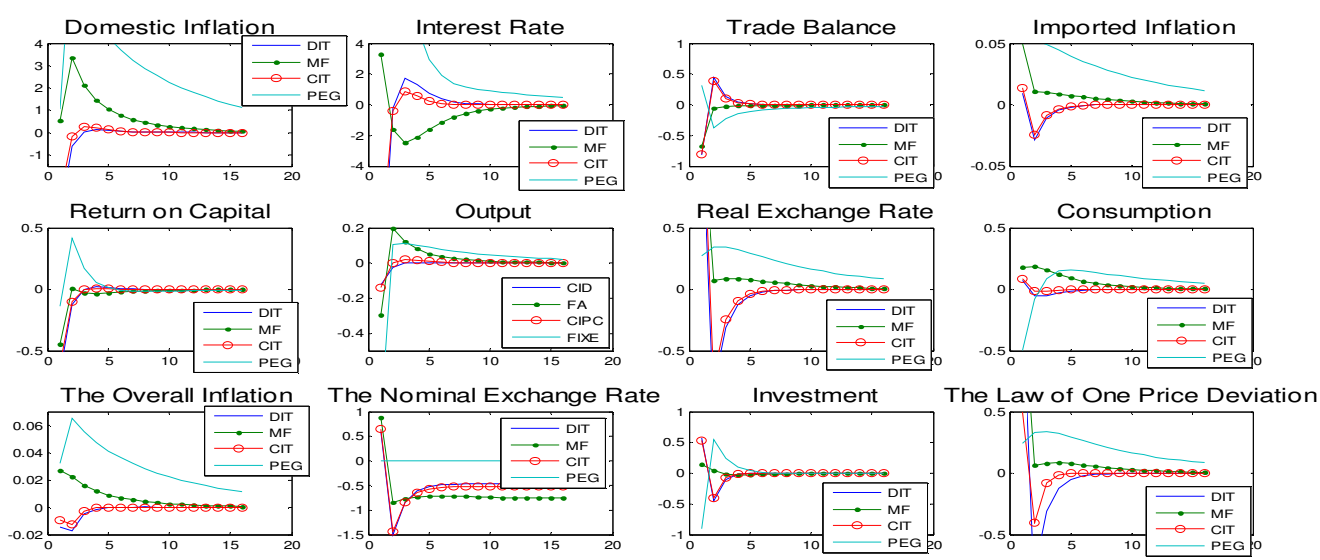

In figure 6, the general conclusions of the previous subsections apply. With immediate pass-through, the DIT monetary rule stabilizes domestic inflation, output and absorption, but does so by generating a high response in the exchange rate, and of both imported and CPI inflation. The DIT rule allows for a sharp, but transitory, nominal depreciation. The anticipated appreciation allows for a fall in the nominal interest rate. By contrast, the MF rule implies a persistent nominal depreciation. As a result, the nominal interest rate rises while the persistent appreciation in CIT decreases the interest rate. In terms of stabilizing output, consumption, and investment in response to the terms of trade deterioration, the four rules are essentially equivalent when there is full passthrough.

Figure 6: Impulse responses to terms of trade shock full pass-through
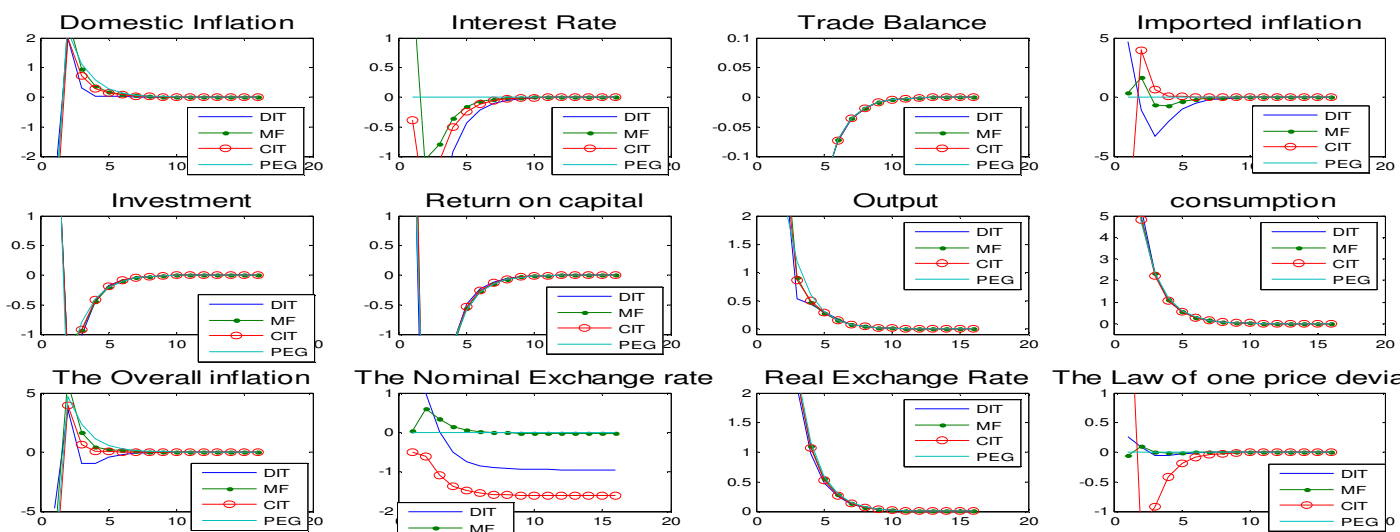

The Nominal Exchange rate

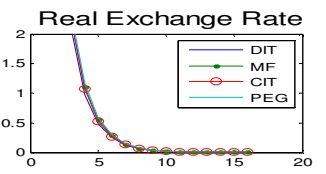

The Law of one price deviation
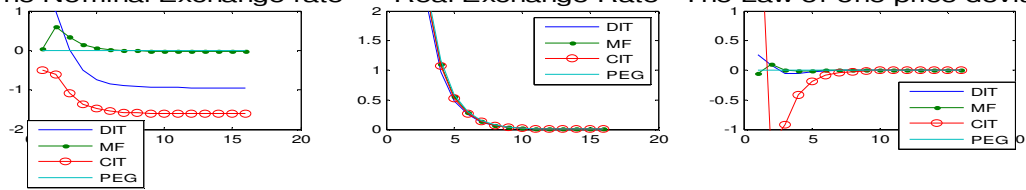


\section{7-Monetary regimes and Macroeconomic Volatility: Sensitivity Analysis}

To conclude my quantitative section, I conduct a sensitivity analysis of the second moments of selected variables to the calibration of three key parameters in the CIT monetary rule under a productivity shock. Figures 7, 8 and 9 display the effect on the volatility of the key macroeconomic variables of varying respectively, the elasticity of substitution between domestic and foreign goods the degree of openness $\alpha$, and the pass-through $\theta$.

Several interesting observations are in order. To begin with, notice that an increase in the elasticity of substitution between domestic and foreign goods increases the volatility of the nominal and the real exchange rates as well as the LOP gap, the output and the inflation. In particular, notice (as it is clear from equation (37)), the dynamics of the consumption depend on $\eta$. A decrease in the elasticity of substitution between domestic and foreign goods lowers the volatility of consumption. In the limit, as $\eta$ becomes null (i.e., as goods become perfectly complementary), that volatility approaches zero. By contrast, when $\eta$ becomes arbitrarily large (i.e., as goods become perfectly substitutable), that volatility rises. In fact, a rise in the elasticity of substitution will see domestic agents substitute out of foreign-produced goods into home produced goods which will decrease the overall consumption.

Consider next the effect of increasing the degree of openness $\alpha$, as displayed in Figure 8. Interestingly, and unlike the conventional wisdom on the effects of exchange rate instability on trade, a higher degree of openness (i.e., trade intensity) has a negative effect on the volatility of the real exchange and nominal exchange rate. Under risk sharing, in fact, and for given fluctuations in relative consumption baskets, a larger degree of openness requires smaller fluctuations in real relative prices. In the limit, as $\alpha \rightarrow 1$, and given the assumption of complete international asset markets, the consumption basket in the small economy corresponds to that of the world economy, with the law of one price implying a constant real exchange rate (and therefore aggregate PPP) and a perfect correlation between domestic and world consumption. The constancy of the real exchange rate stabilizes the LOP gap and, consequently, the imported and the overall inflation (in the limiting case of $\alpha=1$, the LOP gap, the imported and the overall inflation are null).

Under that regime, the lower is $\alpha$, the larger is the variation in domestic prices required to bring about any relative price adjustment. Therefore the key intuition to be applied to the analysis of the CIT rule is that, as long as aggregate PPP does not hold (which is the case for values of $\alpha<1$ ), a lower degree of openness makes exchange rate flexibility more costly by boosting the volatility of inflation and output.

Finally, I look at the effect of varying the pass-through $(\theta)$ measured between 0 and 1.As I approach null passthrough (i.e., $\theta \rightarrow 1$ ), inflation and output volatility are reduced, but at the cost of boosting exchange rate and the LOP gap volatility. On the other hand, under the CIT regime, as $\theta$ approaches 0 , the volatility of both the volatility in LOP gap approaches zero while the volatility of inflation and output rises. In fact, the response of inflation can be explained by the fact that, the nominal exchange rate affects CPI inflation directly with a fullpass-through $(\theta=0)$, while this effect is obviously de-emphasized with incomplete pass-through $(\theta \rightarrow 1)$. Therefore, the results seem consistent with the view that a lower degree of pass-through is associated with higher volatility in exchange rates. Thus, as observed in previous literature (Betts and Devereux 2000), limited passthrough tends to exacerbate exchange rate volatility. But it does so with consequences, because movements in exchange rates do not feed immediately into CPI inflation. Intuitively, the lower the pass-through, the larger will be the variation in nominal exchange rates required to achieve a given adjustment in real relative prices along the transition to the equilibrium. 
Finally, it is worth noticing that varying the degree of pass-through has also a substantial effect on the volatility of the real exchange rate. With incomplete pass-through, the LOP gap contributes to the volatility of the real exchange rate. As emphasized in (section 1.1.2), movement in $\psi_{t}$ contributes to the deviation from PPP and to the volatility of the real exchange rate. Therefore, as long as aggregate PPP does not hold (which is the case for values of $\theta>0$ ), a lower degree of pass-through increases movements in the LOP gap $\psi_{t}$ and according to the equation (19), raises the volatility of the real exchange rate. By contrast, a higher degree of pass-through stabilizes the LOP gap and the real exchange rate. In the limiting case of $\theta=0$, the volatility of the real exchange rate is null.

\section{8-The evaluation of the alternative monetary rules}

I reach three basic results. First, the delayed pass-through cushions the response of the real economy to shocks. In fact, with delayed pass-through (figures 1,3, and 5), changes in exchange rates feed into the CPI only at the rate of overall price adjustment. For the four monetary rules, the lower pass-through stabilizes the rate of inflation. Under the productivity shock for instance, the movement in inflation in DIT is only $10 \%$ of the movement with immediate pass-through. This stabilizes the real economy. The lower response of inflation now allows for a lower real interest rate response to shocks. Regardless of the source of shocks, the movement in output, imported, and overall inflation during the period of the shock is generally much less than in the limited pass-through model (figure 9).

Second, the limited pass-through opens up a substantial difference between the floating and the pegged exchange rate rule. In the former, inflation can now be stabilized while still allowing significant movement in the nominal exchange rate. This implies that the goal of CIT and DIT is still consistently cushioning the nominal and real interest rate response to shocks. As a result, absorption and output under CIT and DIT are much less variable than the pegged exchange rate rule. A flexible exchange rate policy of the type analyzed here can cushion the output response to a shock without requiring more inflation instability. In fact, the response of inflation is greater under the fixed exchange rate than under the flexible exchange rate rule (figures 1, 3 and 5). In response to shocks, incomplete pass-through of changes in the exchange rate to import prices has the effect of eliminating the trade-off between the stabilization of inflation and of the output.

Third, with lagged pass-through, both the domestic and the overall prices respond sluggishly to shocks, and it is more efficient for the monetary authority to target the overall CPI rather than just the domestic prices component (figure 1 and 3 ).

\section{Conclusion}

Contributing to the debates on the optimal exchange rate regime in Morocco, the present paper has developed and analyzed a model of a small open economy with staggered price setting à la Calvo.I have used this framework to analyze the properties of four alternative monetary regimes for a small open economy: (a) domestic inflation targeting, (b) managed float (c) CPI targeting, and (d) an exchange rate peg. The criterion of the choice of the optimal exchange rate regime is based on the examination of the volatility of the macroeconomic variables under the various alternative monetary rules. I conclude from the analysis of the impulse responses that in a low pass-through environment, the floating exchange rate regime, can achieve a simultaneous stabilization of the output and inflation, because the movement in exchange rates do not 
immediately feed into CPI inflation. I also argue that the best monetary policy rule (from a macroeconomic stability viewpoint) in an open economy with lagged pass-through is the CPI targeting rule. By following a price stability rule (CIT rule), the policy-maker can do better than a fixed exchange rate on both counts: both output volatility and inflation volatility may be lower than under a fixed exchange rate.

\section{References}

[1] Abdelkhalek, T. (1996), Élasticités de substitution et de transformation et sensibilités prix et revenu, une Analyse sectorielle du commerce extérieur marocain, Ministère du Commerce Extérieur, Royaume du Maroc.

[2] Basu S. and Kimbal M.S (2002) Long run labor supply and the elasticity of intertemporal substitution of consumption. Working paper university of Michigan.

[3] Benigno, Gianluca and P.P Benigno (2002). "Implementing Monetary Cooperation through Inflation Targeting”. CEPR Discussion Paper No 3226.

[4] Bernake.B.S.M and Gilchrist.S (1999)', The financial accelerator in a quantitative business cycle framework' Princeton University Princeton University, New York University, and Boston University.

[5] Betts, Caroline and M.B. Devereux, 2000. "Exchange Rate Dynamics in a Model with Pricing-to-Market". Journal of International Economics, 50, 215-244.

[6] Bosworth, B and S. Collins (2003): The Empirics of Growth: An Update. Brookings Panel on Economic Activity.

[7] Clarida, Richard, Jordi Gali, and Mark Gertler (2000): "Monetary Policy Rules and Macroeconomic Stability: Evidence and Some Theory', Quarterly Journal of Economics, vol. 105, issue 1, 147-180.

[8] Calvo, G. (1983), "Staggered prices in a utility-maximizing framework", Journal of Monetary Economics, 12, 383-398.

[9] Corsetti G, Kuester K, Meier.A, and Mueller.G. J (2012) Sovereign Risk, Fiscal Policy, and Macroeconomic Stability.IMF Working Paper.Monetary and capital markets department.IMF Working Paper.

[10] Devereux.M.B. Lane.P. and Xu.J(2004) ''Exchange Rates and Monetary Policy in Emerging Market Economies", IIIS Discussion Paper No. 36.

[11]Devereux (1999)'’Monetary Policy, Exchange Rate Flexibility, and Exchange Rate Pass-Through' Bank Canada.

[12] Direction de la politique économique générale(2002)'’La productivité globale des facteurs .Document de travail $n^{\circ} 76$.

[13] Ferrero, A., Gertler, M. and Svensson, L.E.O. 2008. "Current Account Dynamics and Monetary Policy," NBER Working Papers No. 13906.

[14] Gali.J(2008)'’Monetary Policy, Inflation, and the Business Cycle : An introduction to the new Keynesian Framework',

[15] Gali and Monacelli(2004)' 'Monetary Policy and Exchange Rate Volatility in a Small Open Economy', Review of Economic Studies (2005) 72, 707-734.

[16] Gali.J and Monacelli (2002) 'Monetary policy and monetary policy and exchange rate volatility in a small open economy', Working Paper 8905 http://www.nber.org/papers/w8905.National Bureau of Economic Research 1050 Massachusetts Avenue Cambridge, MA 02138. 
[17] Gertler, M., Gilchrist, S., Natalucci, F. M. (2007), "External Constraints on Monetary Policy and the Financial Accelerator", Journal of Money, Credit and Banking, 39(2-3), 295-330.

[18] Goldfajn I. and Werlang S. (2000), « The pass-through from depreciation to inflation: a Panel study», PUC-RIO, Department of Economics, Working Paper, $n^{\circ} 423$, disponible sur Internet www.econ.pucrio.br/pdf/td423.pdf

[19] Haut Commissariat au Plan(2005) 'Les sources de la croissance économique au Maroc"

[20] King R.G and Rebello.S(1999)Resuscitating real business cycles. Working Paper. University of Virginia and University of Northwestern.

[21]King, Robert, Plosser, Charles and Rebelo, sergio (1998). "Production, Growth and Business Cycles: The Basic Neoclassical Model”. Journal of Monetary Economics, 21: 195-232.

[22]Makdissi S., Z. Fattah and I. Limam (2000), "Determinants of Growth in The MENA countries", Global Research Project (GRP) paper.

[23]Monacelli (2003) "Monetary policy in a low pass-through environment". Working paper No227 European Central Bank.

[24] Nehru V. and Dhareshwar A. (1994), "New Estimates of Total Factor Productivity Growth for Developing and Industrial Countries," Policy Research Working Paper N 1313, the World Bank.

[25] Rapport du Ministère de l'Industrie, du Commerce et des Nouvelles Technologies Département du Commerce Extérieur, Direction des Affaires Générales (DAJCE), Cellule des Etudes Economiques et Juridiques "Estimation des élasticités du commerce extérieur du Maroc", Février 2012 (Etude réalisée dans le cadre de la coopération technique avec la Banque Mondiale)".

[26] Senhadji A. (2000), "Sources of Economic Growth: An Extensive Growth Accounting Exercise", IMF Staff Papers, pp. 129-157.

[27] Willems.T (2010)"'Visualizing the invisible: Estimating the New Keynesian Output Gap via a Bayesian Approach”' Working Paper TI 2010-074/2 Tinbergen Institute Discussion Paper. 
Figure 7:Effect on volatility of varying the elasticity of substitution in the CPI targeting facing a productivity shock
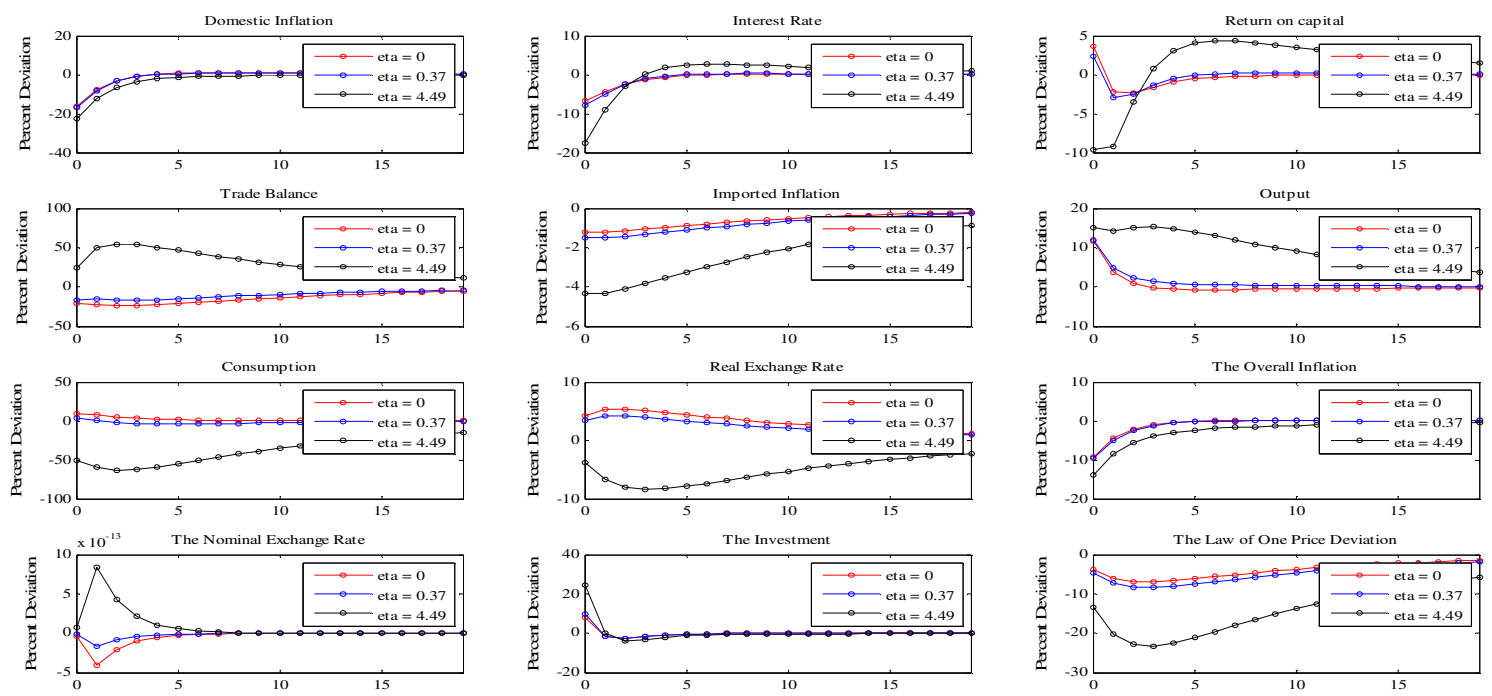

Figure 8:Effect on volatility of varying the degree of openness in the CPI targeting facing a productivity shock
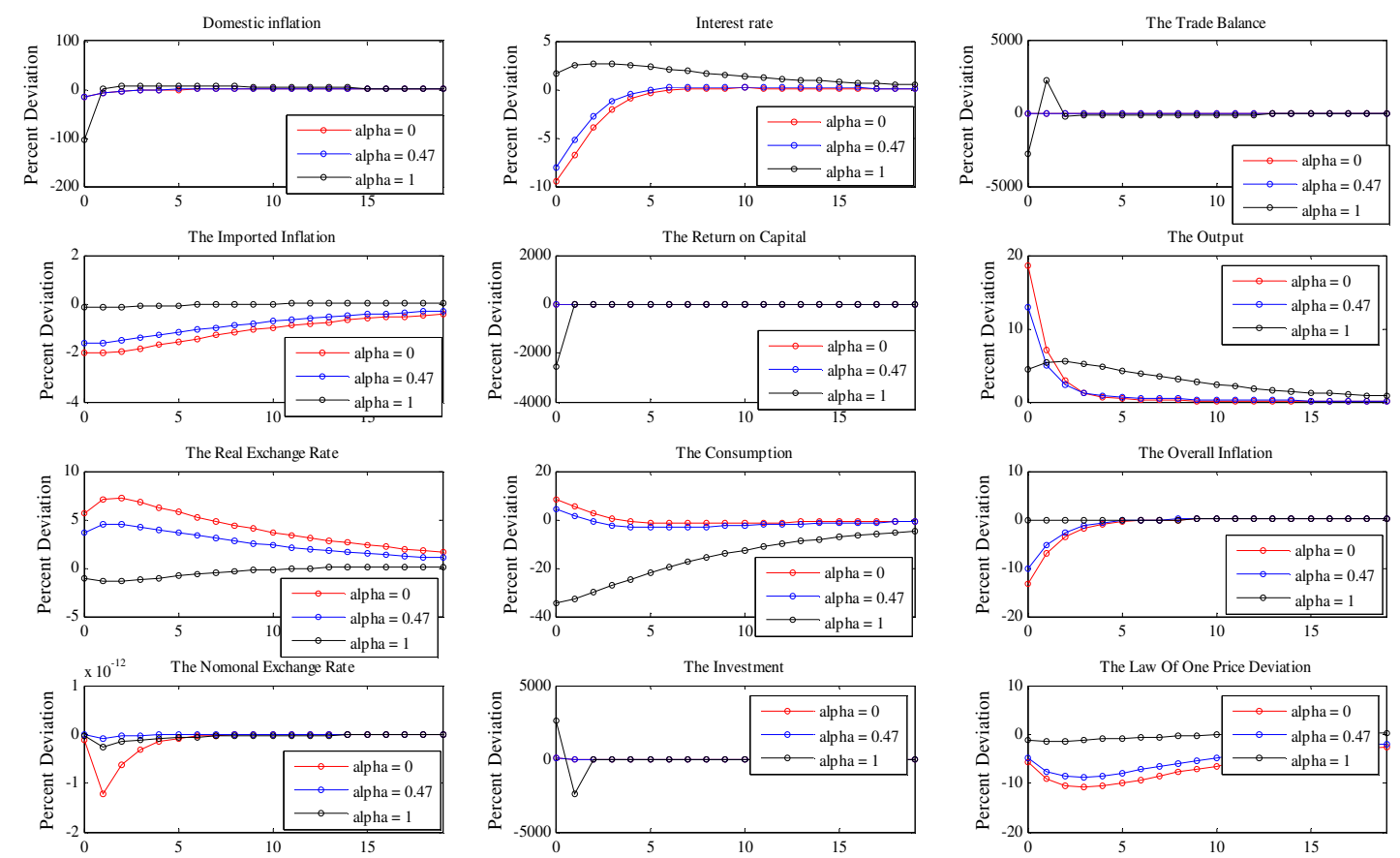
Figure 9:Effect on volatility of varying the degree pass-through in the CPI targeting facing a productivity shock
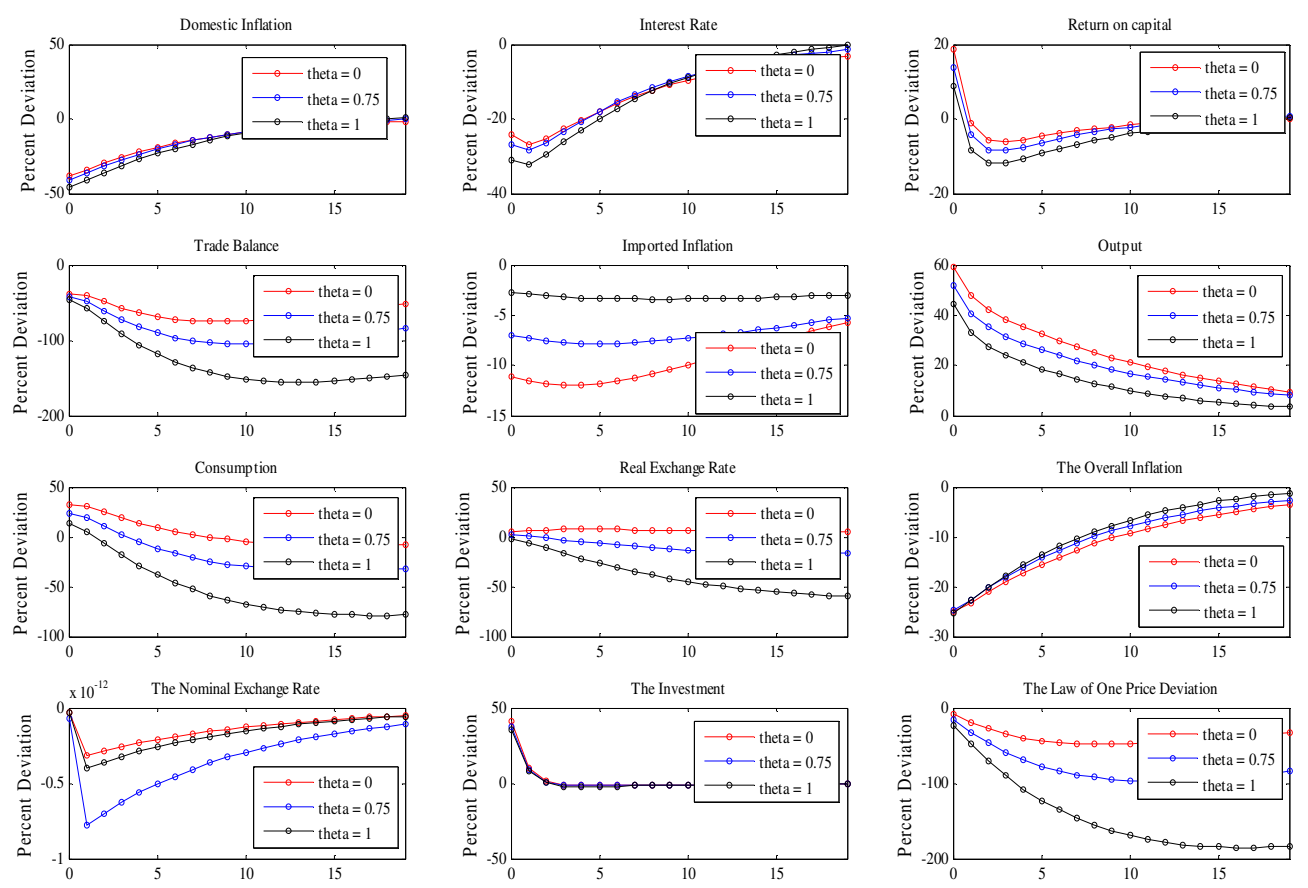
The IISTE is a pioneer in the Open-Access hosting service and academic event management. The aim of the firm is Accelerating Global Knowledge Sharing.

More information about the firm can be found on the homepage:

http://www.iiste.org

\section{CALL FOR JOURNAL PAPERS}

There are more than 30 peer-reviewed academic journals hosted under the hosting platform.

Prospective authors of journals can find the submission instruction on the following page: http://www.iiste.org/journals/ All the journals articles are available online to the readers all over the world without financial, legal, or technical barriers other than those inseparable from gaining access to the internet itself. Paper version of the journals is also available upon request of readers and authors.

\section{MORE RESOURCES}

Book publication information: http://www.iiste.org/book/

Academic conference: http://www.iiste.org/conference/upcoming-conferences-call-for-paper/

\section{IISTE Knowledge Sharing Partners}

EBSCO, Index Copernicus, Ulrich's Periodicals Directory, JournalTOCS, PKP Open Archives Harvester, Bielefeld Academic Search Engine, Elektronische Zeitschriftenbibliothek EZB, Open J-Gate, OCLC WorldCat, Universe Digtial Library, NewJour, Google Scholar

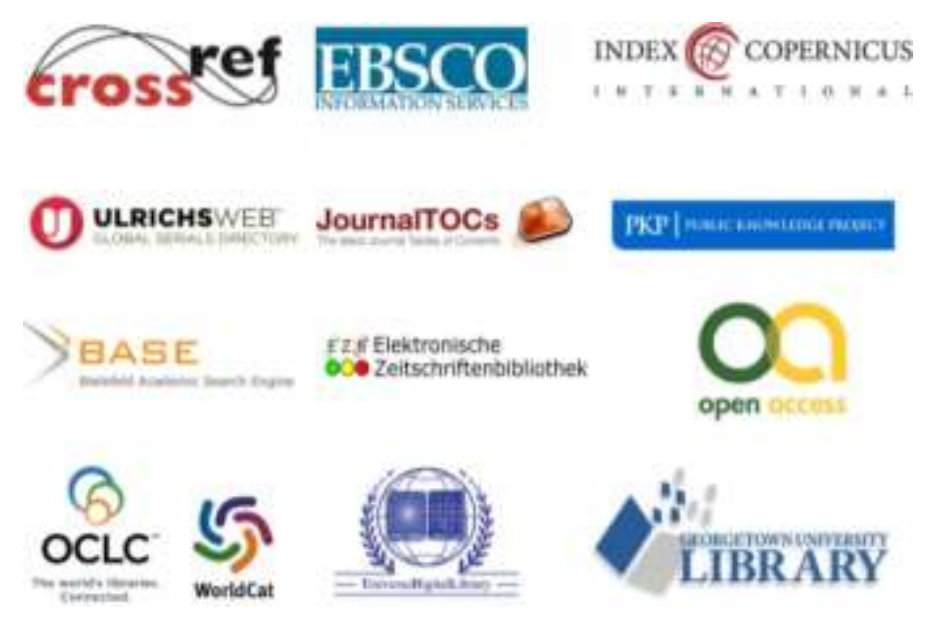

